\title{
Effect of Methyl Methanesulphonate on the Nucleoid Structure of Escherichia coli
}

\author{
By IVAR LOSSIUS, ${ }^{1}$ PER GØRAN KRÜGER ${ }^{2}$ AND KJELL KLEPPE ${ }^{1 *}$ \\ ${ }^{1}$ Department of Biochemistry and ${ }^{2}$ Department of Anatomy, University of Bergen, Bergen, \\ Norway
}

(Received 3 April 1980; revised 13 October 1980)

Incubation of a strain of Escherichia coli $\mathrm{K} 12$ with 25 mM-methyl methanesulphonate (MMS) for $1 \mathrm{~h}$ changed the sedimentation coefficient of the nucleoids from 1600S to 850S. When isolated nucleoids were treated with MMS under identical conditions in vitro there was no change in the sedimentation coefficient. Alkaline sucrose-gradient centrifugation of DNA from cells treated with $25 \mathrm{mM}$-MMS for $1 \mathrm{~h}$ indicated that there were approximately 100 breaks plus apurinic sites per chromosome. Titration with ethidium bromide of nucleoids from MMS-treated cells showed that almost all supercoiling had been lost, suggesting that the breaks plus apurinic sites consisted mostly of breaks. Further experiments showed that the apurinic sites were probably created by non-enzymic depurination and that little non-enzymic strand breakage had occurred. The depurinated sites thus created could then serve as substrates for the apurinic-specific endonucleases of the cell, with the result that strand breakage occurred. MMS treatment did not cause any changes in the DNA : RNA ratio of the nucleoids. Removal of MMS followed by a period of incubation resulted in a decrease in the number of breaks plus apurinic sites and an increase in the sedimentation coefficient of the nucleoids. After $2 \mathrm{~h}$ incubation in MMS-free medium the sedimentation coefficient of the nucleoids from MMS-treated cells was the same as that of the control; the supercoiling was also partially restored.

The effect of MMS on two MMS-sensitive mutants of E. coli, one a polA and the other a recA mutant, was also studied. In both cases MMS caused complete collapse of the nucleoid structure.

\section{INTRODUCTION}

In bacteria the chromosome exists as a compact, supercoiled structure often termed a nucleoid (Pettijohn, 1976; Kleppe et al., 1979). The nucleoid can be isolated free from cell envelope components and its properties studied in vitro (Stonington \& Pettijohn, 1971; Pettijohn et al., 1973; Drlica \& Worcel, 1975; Kavenoff \& Bowen, 1976; Hecht et al., 1977). The nucleoid structure is affected by the physiological conditions of the cell and by chemicals (Worcel \& Burgi, 1972; Dworsky \& Schaechter, 1973; Korch et al., 1976; Lydersen \& Pettijohn, 1977; Drlica \& Snyder, 1978; Kleppe \& Lossius, 1978; Øvrebø \& Korch, 1978). In order to gain a better understanding of the mechanism of action of mutagenic compounds as well as the structure of the nucleoid both in vivo and in vitro, we have studied the changes that take place in the nucleoid structure when cells are treated with various mutagenic agents (Kleppe \& Lossius, 1978). The present work deals with the effect of the monofunctional alkylating agent methyl methanesulphonate (MMS) on a mutant of Escherichia coli $\mathrm{K} 12$ that has been used previously in studies of the nucleoid, and on two MMS-sensitive strains.

The main effect of MMS is to methylate the purine residues in DNA and RNA and amino acid residues in proteins (Lawley, 1966, 1974; Rhaese \& Freese, 1969; Prakash \& Strauss, 
1970; Singer, 1975, 1977). The methylated bases in DNA are only slowly excised by repair enzymes. Non-enzymic depurination of methylated bases as well as specific strand cleavage are also known to occur (Singer, 1975). Several mutants of $E$. coli, such as those with mutations in polA, $\operatorname{rec} A, \operatorname{rec} B$ and $\operatorname{rec} C$, are particularly sensitive to MMS (HowardFlanders \& Boyce, 1966; Gross \& Gross, 1969; Bridges et al., 1973; Thielmann et al., 1975). These mutants are also sensitive to u.v. light and $\gamma$ radiation and it is likely, therefore, that they are defective in some common steps in DNA repair. A mutant of $E$. coli which is sensitive to MMS but only slightly sensitive to u.v. light has been reported by Ljungquist et al. (1976). It proved to be a double mutant with mutations in the polA and the $x$ thA genes, i.e. it is defective in both DNA polymerase I and an endonuclease specific for apurinic DNA. More recently, a new type of MMS-sensitive mutant not sensitive to u.v. light and $\gamma$ radiation has also been isolated (Yamamoto et al., 1978). The function of the mutated gene is not known and it maps in a different position from the $x t h A$ gene. In the case of $E$. coli $\mathrm{K} 12$ it has also been shown that the MMS-sensitivity of $\mathrm{rec}^{+}$strains is to some extent dependent on the medium in which they are grown (Scudiro et al., 1973). Cells grown in glucose-enriched nutrient broth medium were more resistant than cells grown in nutrient broth only.

The present work shows that treatment of $E$. coli $\mathrm{K} 12$ with MMS results in marked changes in the nucleoid structure. In particular, loss of supercoiling (caused by the introduction of breaks into the DNA) was observed, the supercoiling being partially restored during incubation after the removal of MMS.

\section{METHODS}

Chemicals and nucleic acids. Polyoxyethylene(20) cetyl ether (Brij-58), ethidium bromide and egg white lysozyme Igrade I, 46360 units (mg protein) ${ }^{-1} \mid$ were obtained from Sigma. Sodium deoxycholate and MMS were purchased from Merck, and Sarkosyl NL-97 from Ciba-Geigy. Radiochemicals were obtained from The Radiochemical Centre, Amersham. All other chemicals used were reagent grade. ${ }^{3} \mathrm{H}$-Labelled $\phi$ X 174 RFI (specific activity $0.1 \mu \mathrm{Ci}_{\mu \mathrm{g}}{ }^{-1}, 3.7 \mathrm{kBq} \mathrm{g}^{-1}$ ) was a gift from I. F. Nes, Department of Biochemistry, University of Bergen, Norway (Nes \& Nissen-Meyer, 1978). ${ }^{14} \mathrm{C}$-Labelled phage T4 was prepared by the method of Eisenstark (1967).

Bacterial strains. The following strains were used: Escherichia coli $\mathrm{K} 12 \mathrm{DG} 75\left(\mathrm{~F}^{-}\right.$thy leu), E. coli $\mathrm{K} 12$ $\mathrm{AB} 2463$ ( recA thr leu his arg pro), and E. coli $3478\left(\mathrm{~F}^{-}\right.$thy A36 polA1).

Growth conditions. All strains were grown for $2 \mathrm{~h}$ at $37^{\circ} \mathrm{C}$ in L-broth supplemented with $10 \mu \mathrm{g}$ thymine $\mathrm{ml}^{-1}$ and $2 \mathrm{mg}$ glucose $\mathrm{ml}^{-1}$. Dilutions were then made into the minimal medium of Clark \& Maaløe (1967), with the following additions (per ml): for E. coli K12 DG75 (thyleu), $1 \mu \mathrm{g}$ thiamin, $5 \mu \mathrm{g}$ thymidine and $80 \mu \mathrm{g}$-leucine; for E. coli $\mathrm{p} 3478$ (thyA36 polA1), $1 \mu \mathrm{g}$ thiamin and $5 \mu \mathrm{g}$ thymine: for E. coli $\mathrm{K} 12 \mathrm{AB} 2463$ (recA thr leu his arg pro), $1 \mu \mathrm{g}$ thiamin and $10 \mu \mathrm{g}$ each of $\mathrm{L}$-threonine, $\mathrm{L}$-leucine, $\mathrm{L}$-histidine, $\mathrm{L}$-arginine and $\mathrm{L}$-proline. After overnight growth at $37^{\circ} \mathrm{C}$, to an $A_{450}$ of $0 \cdot 4$, the cells were used in the experiments.

Viability after MMS treatment. Both control and MMS-treated cells were harvested by centrifugation at 7500 rev. $\min ^{-1}$ for $5 \mathrm{~min}$ in an HB-4 rotor using a Sorvall RC-5 centrifuge. Dilution series were made with minimal medium. Samples of $100 \mu \mathrm{l}$ were plated on $1.5 \%(\mathrm{w} / \mathrm{v})$ agar containing the same medium and incubated for $24 \mathrm{~h}$ at $37^{\circ} \mathrm{C}$ before counting.

Labelling. DNA was labelled with $1.0-30 \mu \mathrm{Ci} \mid$ methyl ${ }^{-3} \mathrm{H} \mid$ thymidine $\mathrm{ml}^{-1}\left(47 \mathrm{Ci} \mathrm{mmol}^{-1}: 1.74 \mathrm{TBq}^{-1} \mathrm{mmol}^{-1}\right)$ for 5 min. The DNA in the MMS-treated cells was labelled before the addition of MMS. For simultaneous labelling of DNA and RNA, cells were treated with $7.5 \mu \mathrm{Ci} \mid 5{ }^{-}{ }^{3} \mathrm{H} /$ uracil $\mathrm{ml}^{-1}\left(1 \mathrm{Ci} \mathrm{mmol}{ }^{-1} ; 37 \mathrm{GBq} \mathrm{mmol}{ }^{-1}\right)$ for two generations. In experiments to measure the rate of DNA synthesis, $1 \mathrm{ml}$ samples were withdrawn at the times indicated and were pulse-labelled for 2 min with $0.3-1.25 \mu \mathrm{Ci} \mid$ methyl ${ }^{3} \mathrm{H} \mid$ thymidine $\mathrm{ml}^{-1}\left(47 \mathrm{Ci} \mathrm{mmol}^{-1}\right)$. The number of methyl groups introduced into DNA by MMS was estimated using $\mid$ methy/ $/{ }^{14} \mathrm{C} \mid \mathrm{MMS}(0.2 \mathrm{mCi}$ $\mathrm{mmol}^{-1}: 7 \cdot 4 \mathrm{MBq} \mathrm{mmol}^{-1}$ ).

In vivo MMS treatment. MMS was added to an exponentially growing culture in the minimal medium of Clark \& Maaløe (1967). The cells were incubated at $37^{\circ} \mathrm{C}, \mathrm{pH} \mathrm{7.0}$, and harvested by filtration on Millipore filters (RAWP $04700,0.45 \mu \mathrm{m}$ ). In experiments to measure viability, the cells were harvested by centrifugation.

In vitro MMS treatment of envelope-free nucleoids. Envelope-free nucleoids were isolated by sucrose-gradient centrifugation (see below). The fractions containing the 1500-1700S nucleoids were treated with various concentrations of MMS at $\mathrm{pH} 7.0$ and at $0,10,20$ and $37^{\circ} \mathrm{C}$ for 30 or $60 \mathrm{~min}$. In addition to MMS, the incubation mixture contained $1 \mathrm{M}-\mathrm{NaCl}, 5 \mathrm{mM}$-EDTA and $10 \mathrm{~mm}$-Tris $\mathrm{pH} 7.0$. 
Preparation of envelope-free nucleoids. Approximately $3 \mathrm{ml}$ of an exponentially growing culture with an $A_{450}$ of

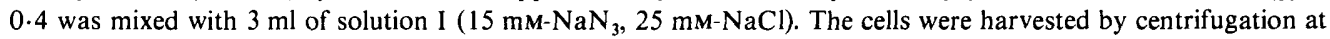
7500 rev. $\min ^{-1}$ for $5 \mathrm{~min}$ in an HB-4 rotor using a Sorvall RC-5 centrifuge. The pellet was resuspended in $400 \mu \mathrm{l}$ of ice-cold solution II (10 mM-NaN $, 0.1 \mathrm{M}-\mathrm{NaCl}, 20 \%$ sucrose, $10 \mathrm{~mm}$-Tris pH 8.2). A $200 \mu \mathrm{l}$ portion of this suspension was gently mixed with $50 \mu \mathrm{l}$ of ice-cold solution III (4 mg egg white lysozyme $\mathrm{ml}^{-1}, 50 \mathrm{mM}-\mathrm{EDTA}$, $0.12 \mathrm{M}$-Tris $\mathrm{pH} 8.2)$ and incubated for $10 \mathrm{~min}$ at $0^{\circ} \mathrm{C}$. A $250 \mu \mathrm{l}$ portion of ice-cold solution IV $(2 \mathrm{M}-\mathrm{NaCl}$, 10 mm-EDTA, $1 \%$ Brij-58, $1 \%$ Sarkosyl NL-97, 0.4\% sodium deoxycholate) was then added and the mixture was incubated for $10 \mathrm{~min}$ at $20^{\circ} \mathrm{C}$. The lysate $(400 \mu \mathrm{l})$ was slowly $\left(0.8 \mathrm{ml} \mathrm{min}^{-1}\right)$ applied to a gradient of $10-30 \%$ $(\mathrm{w} / \mathrm{v})$ sucrose containing $1 \mathrm{M}-\mathrm{NaCl}, 5 \mathrm{~mm}$-EDTA, $1 \mathrm{~mm}$-2-mercaptoethanol and $10 \mathrm{~mm}$-Tris $\mathrm{pH} 8 \cdot 2$. The gradient tubes were centrifuged at 10000 rev. $\min ^{-1}$ for $2 \mathrm{~h}$ at $4{ }^{\circ} \mathrm{C}$ either in an HB-4 rotor using a Sorvall RC-5 centrifuge or in an SW41 Ti rotor using a Beckman L2-65B centrifuge. The lysates were not pre-centrifuged to remove cell debris (Korch et al., 1976). ${ }^{14} \mathrm{C}$-Labelled phage T4 was used as a marker. Approximately 30 fractions per gradient were collected by pumping out from the bottom of the gradient. The fractions were either subjected to cold trichloroacetic acid treatment, filtered on Gelman glass fibre filters (type A-E) and washed three times with cold trichloroacetic acid, or alternatively $100 \mu \mathrm{l}$ samples of each fraction were applied to Whatman $3 \mathrm{MM}$ filters. All filters were dried in a vacuum oven at $80^{\circ} \mathrm{C}$ for $45 \mathrm{~min}$ and counted in $2.5 \mathrm{ml}$ of a toluene-based scintillation fluid.

Determination of sedimentation coefficients. Calibration of the $10-30 \%$ sucrose gradient system using phage T4 gave a linear correlation between $R_{F}$ value and sedimentation coefficient in the range from 500S to 2000S (Korch et al., 1976). The sedimentation coefficients were not corrected for rotor speed effects (Hecht et al., 1977).

Measurement of RNA co-sedimenting with the envelope-free nucleoids. Lysates were made from cells labelled with $\left[5 \cdot{ }^{3} \mathrm{H}\right]$ uracil for two generations. Centrifugation and fractionation of the gradients were carried out as described above and the fractions were analysed for DNA and RNA according to Kennel (1967).

Titration of supercoiling. Bacterial lysates were prepared as described above. Samples of $100 \mu \mathrm{l}$ from the same lysate were applied to gradient tubes containing different concentrations of ethidium bromide. The gradient tubes were then centrifuged at $10000 \mathrm{rev} . \mathrm{min}^{-1}$ for $2 \mathrm{~h}$ at $4{ }^{\circ} \mathrm{C}$ in an SW41 Ti rotor using a Beckman L2-65B centrifuge and fractionated as described above, and the sedimentation coefficient of the nucleoids was determined.

Determination of molecular weight of DNA by centrifugation in alkaline sucrose gradients. Lysates from MMS-treated and untreated cells were prepared as described above. Samples of $200 \mu \mathrm{l}$ of the lysate were layered on to $5 \mathrm{ml}$ gradients of $5-20 \%$ sucrose containing $0.3 \mathrm{M}-\mathrm{NaOH}, 1 \mathrm{M}-\mathrm{NaCl}$ and $5 \mathrm{mM}$-EDTA. The gradients were centrifuged at 40000 rev. $\mathrm{min}^{-1}$ for $80 \mathrm{~min}$ at $4{ }^{\circ} \mathrm{C}$ in an SW50.1 Ti rotor using a Spinco L-50 centrifuge. $\phi \mathrm{X} 174$ RFI was used as an internal marker in all gradients. The molecular weights were calculated using the equation of Studier (1965) for alkaline single-stranded DNA. The number of single-strand breaks was estimated from the equation $N=\left(M_{0} / M_{\mathrm{x}}\right)-1$, where $N$ is the number of single-strand breaks, $M_{\mathrm{x}}$ is the molecular weight of nicked DNA and $M_{0}$ is the molecular weight of non-nicked DNA.

Determination of the number of methyl groups introduced into DNA by MMS. The cells were grown in the presence of $25 \mathrm{mM}-1{ }^{14} \mathrm{CIMMS}\left(210 \mu \mathrm{Ci} \mathrm{mmol}^{-1}\right)$ for $1 \mathrm{~h}$ at $37^{\circ} \mathrm{C}$. DNA, RNA and protein were separated according to Kennel (1967), and the radioactivity in each fraction was determined.

Determination of the number of single-strand breaks plus apurinic sites in DNA after MMS treatment. $\phi \mathrm{X} 174$ RFI $\left(0.64 \mu \mathrm{g} \mathrm{ml}^{-1}\right)$ labelled with $\left[\right.$ methyl ${ }^{3} \mathrm{H}$ ]thymidine $\left(0.1 \mu \mathrm{Ci} \mu \mathrm{g}^{-1}\right)$ was incubated with $25 \mathrm{mM}$-MMS for $60 \mathrm{~min}$ at $37^{\circ} \mathrm{C}$ in a buffer containing $10 \mathrm{~mm}$-EDTA and $10 \mathrm{~mm}$-Tris pH 7.6. Samples of $200 \mu \mathrm{l}$ were applied to alkaline 5-20\% sucrose gradients and centrifuged at 40000 rev. $\min ^{-1}$ for $4 \mathrm{~h}$ at $4{ }^{\circ} \mathrm{C}$ in an SW 41 Ti rotor using a Beckman L2-65B centrifuge. The number of single-strand breaks plus apurinic sites was calculated according to Brent (1975).

Determination of breaks due to non-enzymic hydrolysis of apurinic sites and triester breakage in MMS-treated $\phi X 174$ RFI. $\phi$ X174 RFI was treated with MMS as described in the preceding section. Samples of $200 \mu l$ were applied to gradients of $5-20 \%$ sucrose containing $10 \mathrm{~mm}$-EDTA and $10 \mathrm{~mm}$-Tris $\mathrm{pH} 7.6$ and centrifuged at 40000 rev. $\min ^{-1}$ for $7.5 \mathrm{~h}$ in an SW41 Ti rotor using a Beckman L2-65B centrifuge. The number of breaks was determined from the conversion of the RFI to the RFII form.

Transmission electron microscopy of E. coli. The bacteria were immediately chilled and fixed with glutaraldehyde and osmium tetroxide, then embedded and post-stained according to Krüger \& Bloom (1974). Thin sections were examined in a Philips EM300 electron microscope.

\section{RESULTS}

\section{Effect of MMS on growth and morphology of E. coli K12 DG75}

Escherichia coli $\mathrm{K} 12$ DG75 was used for most of the experiments reported here since this strain has been employed extensively in other studies on nucleoids (Worcel \& Burgi, 1975; Korch et al., 1976; Øvrebø \& Korch, 1978). Prior to the nucleoid experiments it was necessary to investigate the influence of MMS on growth, survival and morphology of this 

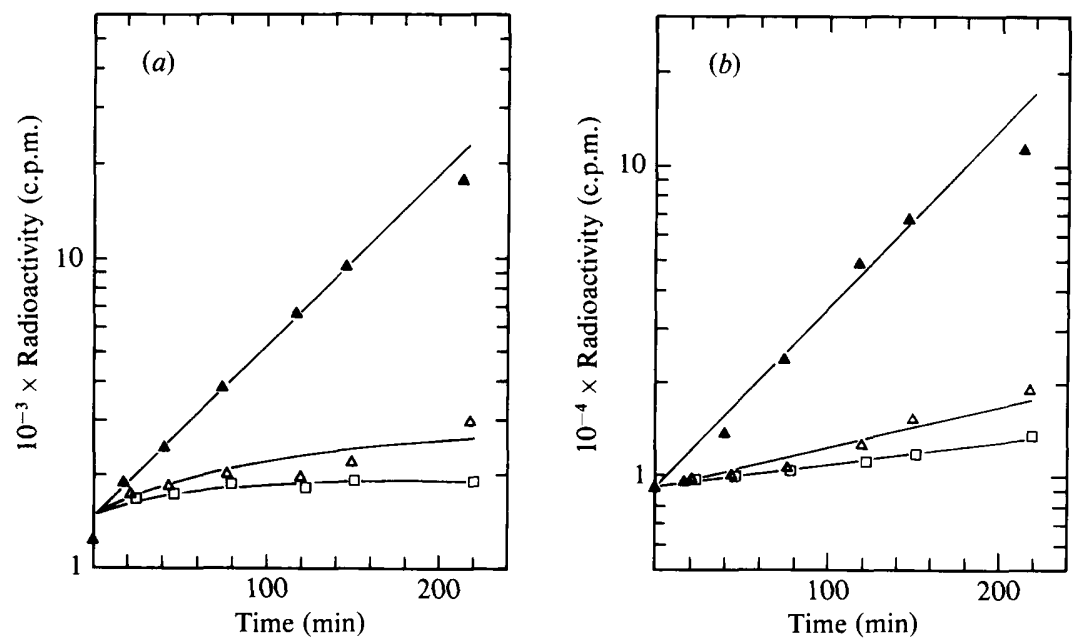

Fig. 1. Effect of MMS on DNA synthesis (a) and RNA synthesis (b) in $E$. coli $\mathrm{K} 12$ DG75. The cells were labelled with $\left[{ }^{3} \mathrm{H}\right]$ uracil $\left(2.5 \mu \mathrm{g} \mathrm{ml}^{-1}, 2 \mu \mathrm{Ci} \mathrm{mmol}^{-1}\right)$ and MMS was added at $t=0$. Further details are given in Methods. Control $(\Delta)$; cells treated with 10 mM-MMS $(\triangle)$; cells treated with 25 mM-MMS (口).

strain. The rate of growth, as measured by the increase in the $A_{450}$, decreased approximately $50 \%$ in the presence of $10 \mathrm{mM}$-MMS, whereas $25 \mathrm{mM}$-MMS caused at least $90 \%$ inhibition. Plating for surviving bacteria showed that treatment with $25 \mathrm{mM}-\mathrm{MMS}$ for $1 \mathrm{~h}$ at $37^{\circ} \mathrm{C}$ yielded approximately $2 \%$ surviving cells. The corresponding number with $10 \mathrm{mM}$-MMS was approximately $20 \%$. The survival decreased linearly with time when plotted semilogarithmically. From these results it was concluded that E. coli K12 DG75 resembles other strains not sensitive to MMS (Lungquist et al., 1976). The influence of MMS on DNA and RNA synthesis in $E$. coli K12 DG75 is shown in Fig. 1 . MMS at $25 \mathrm{mM}$ caused almost complete inhibition of both DNA and RNA synthesis.

The number of methylated bases in the DNA of E. coli K12 DG75 was measured using $\left[{ }^{14} \mathrm{C}\right] \mathrm{MMS}$. After incubation for $1 \mathrm{~h}$ with $25 \mathrm{mM}-\mathrm{MMS}, 50 \%$ of the radioactivity was found in the protein fraction, $41 \%$ in RNA and $9 \%$ in DNA. In the case of DNA it was established that approximately $0.6 \%$ of the bases had been methylated.

Thin sections of $E$. coli K12 DG75 treated with MMS were examined by transmission electron microscopy. Some representative examples are shown in Fig. 2. The nuclear areas are less visible in the MMS-treated cells compared with the control cells. Another characteristic feature of the MMS-treated cells is their loss of shape and septum formation and an increase in the periplasmic space, particularly evident at the ends of the cells. Examination of MMS-treated cells by phase-contrast microscopy showed that the nuclear zone in these cells became less visible with time (results not shown).

\section{Effect of MMS on the sedimentation properties of envelope-free nucleoids}

The banding pattern of envelope-free nucleoids isolated from untreated cells of $E$. coli $\mathrm{K} 12$ DG75 showed a symmetrical peak with a sedimentation coefficient of approximately $1600 \mathrm{~S}$ (Fig. $3 a$ ). No change in the sedimentation coefficient was observed when the cells were treated with $25 \mathrm{mM}$-MMS for $30 \mathrm{~min}$ (Fig. $3 \mathrm{~b}$ ), but after $60 \mathrm{~min}$ the sedimentation coefficient had decreased to approximately $850 \mathrm{~S}$ (Fig. $3 \mathrm{c}$ ). With $10 \mathrm{mM}$-MMS there was no change in the sedimentation coefficient after $30 \mathrm{~min}$ treatment, but after $60 \mathrm{~min}$ it had decreased to approximately $1350 \mathrm{~S}$ (results not shown). 

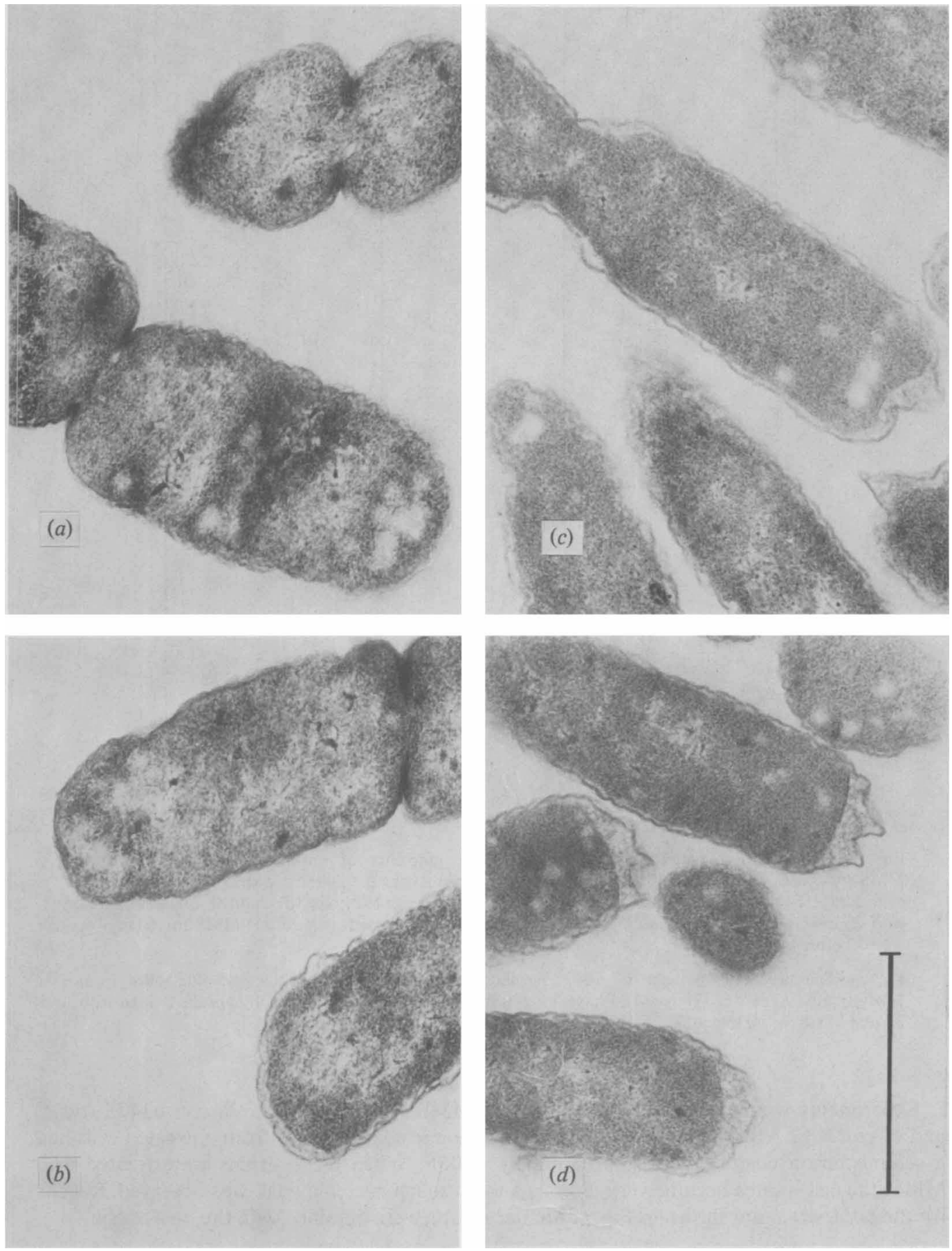

Fig. 2. Transmission electron micrographs of thin sections of MMS-treated E. coli K12 DG75. $(a, b)$ Controls; $(c, d)$ cells treated with $25 \mathrm{~mm}$-MMS for $1 \mathrm{~h}$ at $37^{\circ} \mathrm{C}$. The bar marker represents $1 \mu \mathrm{m}$.

The influence of MMS treatment on the sedimentation properties of isolated envelope-free nucleoids was also investigated. Treatment of isolated nucleoids with $25 \mathrm{mM}$-MMS for 30 or 60 min caused no change in the sedimentation coefficient (results not shown). 


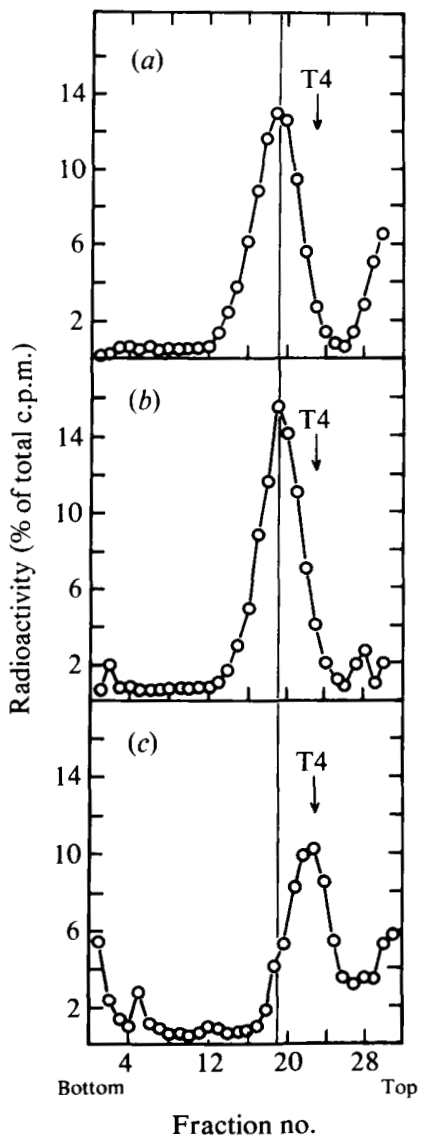

Fig. 3

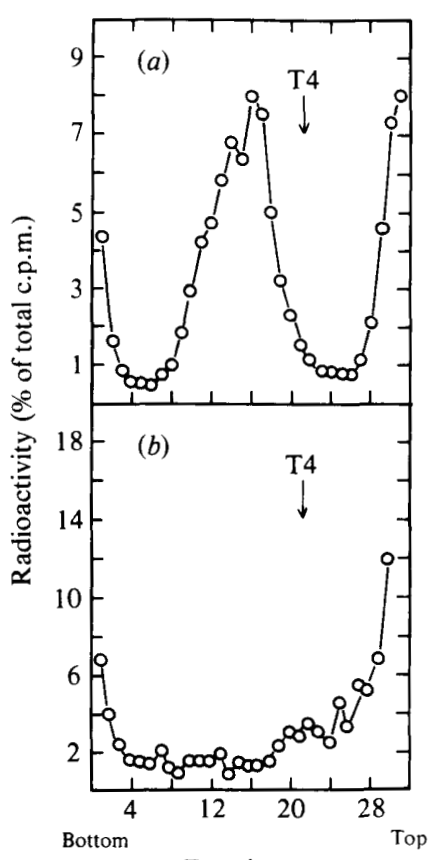

Fraction no.

Fig. 4

Fig. 3. Sedimentation pattern in $10-30 \%$ sucrose gradients of envelope-free nucleoids from MMS-treated $E$. coli $\mathrm{K} 12 \mathrm{DG} 75$. The DNA in all fractions was precipitated with cold trichloroacetic acid. Phage T4 was used as a marker. Further details are given in Methods. (a) Control; $(b)$ cells treated with $25 \mathrm{mM}$-MMS for $30 \mathrm{~min}$ at $37^{\circ} \mathrm{C}$ before lysis; (c) cells treated with $25 \mathrm{mM}$-MMS for $60 \mathrm{~min}$ at $37^{\circ} \mathrm{C}$ before lysis.

Fig. 4. Sedimentation pattern in $10-30 \%$ sucrose gradients of envelope-free nucleoids from MMS-treated E. coli p3478 (polA). Phage T4 was used as a marker. $(a)$ Control; $(b)$ cells treated with $25 \mathrm{~mm}-\mathrm{MMS}$ for $60 \mathrm{~min}$ at $37^{\circ} \mathrm{C}$ before lysis.

Experiments were also carried out with two MMS-sensitive strains, $E$. coli p3478 (polA) and $E$. coli $\mathrm{K} 12 \mathrm{AB} 2463$ ( $\mathrm{rec} A$ ). In both cases the nucleoids isolated from untreated cells had a sedimentation coefficient of approximately $1600 \mathrm{~S}$. When these strains were treated with MMS, the cell lysates became very viscous and no sharp nucleoid peak was observed. Results for the polA strain are shown in Fig. 4. Similar results were obtained with the rec $A$ strain.

\section{Loss of supercoiling during MMS treatment}

The marked change in the sedimentation coefficient of nucleoids that occurred when $E$. coli K 12 DG 75 was treated with MMS could be due to several factors, such as loss of RNA and therefore changes in the DNA : RNA ratio of the nucleoid, or nicking of DNA resulting in decreased supercoiling with a partial unfolding of the nucleoid. By labelling the nucleoid with $\left[{ }^{3} \mathrm{H}\right]$ uracil the amounts of DNA and RNA in the nucleoid could be estimated (Table 1). The 
Table 1. RNA content of envelope-free nucleoids from cells treated with MMS

The cells were labelled with $\left[5-{ }^{3} \mathrm{H}\right]$ uracil for two generations and treated with MMS for 60 min at $37{ }^{\circ} \mathrm{C}$ before lysis. The envelope-free nucleoids were isolated by sucrose-gradient centrifugation and RNA and DNA were determined according to Kennel (1967).

\begin{tabular}{|c|c|c|c|c|}
\hline \multirow[b]{2}{*}{ Treatment } & \multicolumn{3}{|c|}{$\begin{array}{l}\text { Radioactivity in nucleic acid fractions } \\
\text { (c.p.m.) }\end{array}$} & \multirow{2}{*}{$\begin{array}{c}\text { Percentage of total } \\
\text { RNA radioactivity } \\
\text { co-sedimenting with nucleoid }\end{array}$} \\
\hline & DNA peak & RNA peak & DNA : RNA & \\
\hline None & 2360 & 870 & 2.71 & 0.7 \\
\hline $10 \mathrm{mM}-\mathrm{MMS}$ & 500 & 171 & 2.92 & 0.9 \\
\hline 25 mM-MMS & 366 & 135 & $2 \cdot 71$ & 0.7 \\
\hline
\end{tabular}

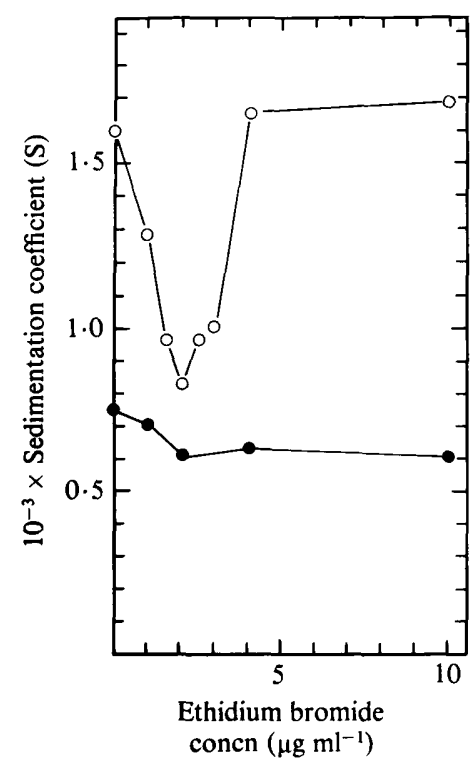

Fig. 5. Sedimentation coefficient as a function of ethidium bromide concentration for envelope-free nucleoids from MMS-treated $E$. coli K 12 DG75. Further details are given in Methods. Control $(O)$; cells treated with $25 \mathrm{mM}-\mathrm{MMS}$ for $1 \mathrm{~h}$ at $37^{\circ} \mathrm{C}$ before lysis (O).

results show that the DNA : RNA ratio in the nucleoid was the same in the MMS-treated and in the control cells.

The amount of supercoiling in the nucleoid can be determined by titration with ethidium bromide (Worcel \& Burgi, 1972). Increasing concentrations of ethidium bromide were used in a set of sucrose gradient tubes, and for each concentration the sedimentation coefficient of the nucleoid was calculated. The result from one such experiment is shown in Fig. 5. In the control a minimum sedimentation coefficient was observed at a concentration of ethidium bromide of approximately $2 \mu \mathrm{g} \mathrm{ml}^{-1}$. Above this concentration the sedimentation coefficient again increased and reached the initial value at a concentration of ethidium bromide of $4 \mu \mathrm{g}$ $\mathrm{ml}^{-1}$. The pattern obtained for the control is similar to that reported by other groups (Worcel \& Burgi, 1972; Pettijohn \& Hecht, 1973). In the case of the nucleoids isolated from cells that had been treated with $25 \mathrm{mM}$-MMS for $1 \mathrm{~h}$, increasing concentrations of ethidium bromide had little effect on the sedimentation coefficient. These results suggest that the nucleoid from the MMS-treated cells had lost almost all its supercoiling. This could have been caused by repair nucleases which introduce single-strand breaks in the DNA at modified sites or by 


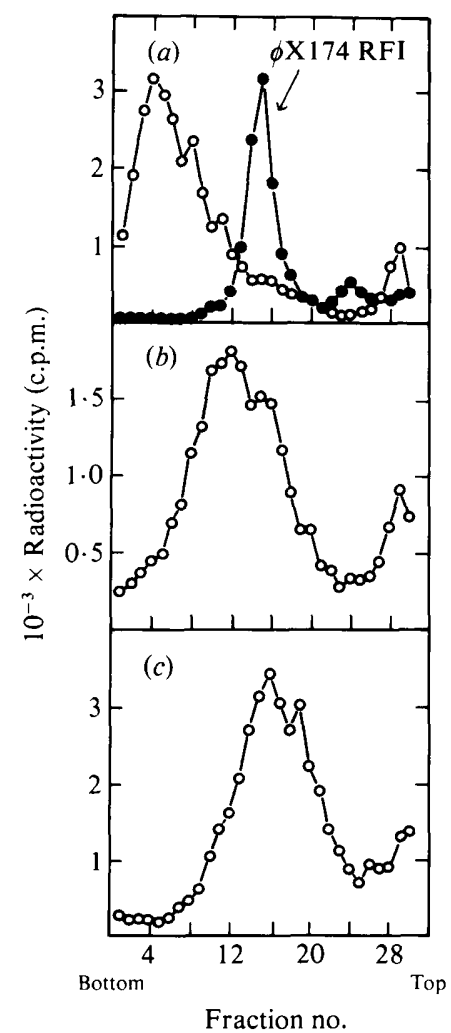

Fig. 6

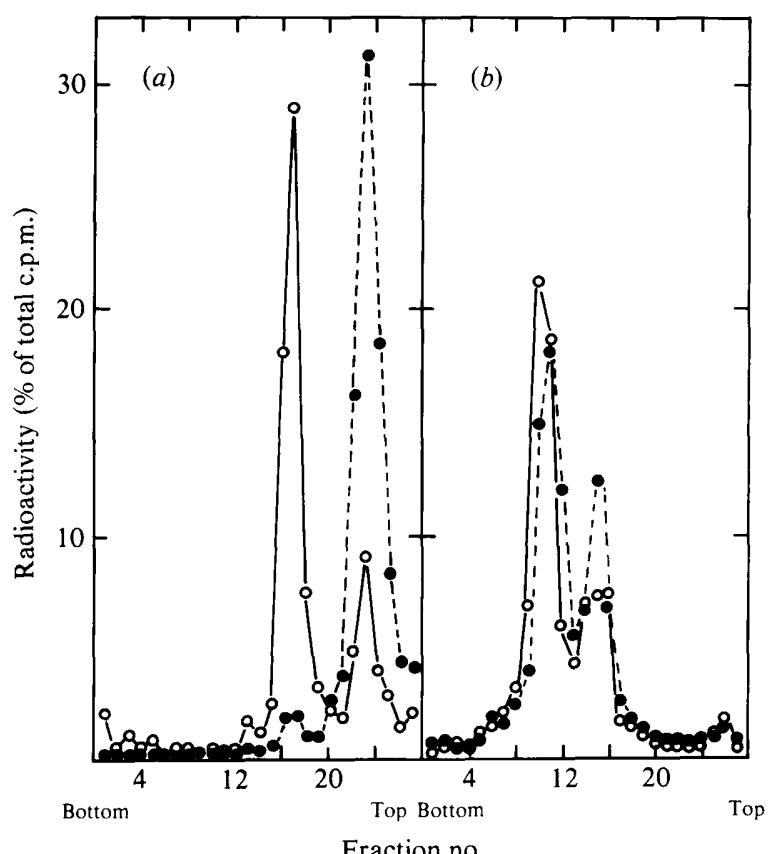

Fraction no.

Fig. 7

Fig. 6. Sedimentation pattern in alkaline 5-20\% sucrose gradients of DNA from MMS-treated $E$. coli K 12 DG75. $\phi$ X174 RFI was used as a marker. (a) Control; $(b)$ cells treated with $10 \mathrm{mM}-\mathrm{MMS}$ for $1 \mathrm{~h}$ at $37^{\circ} \mathrm{C}$ before lysis; $(c)$ cells treated with $25 \mathrm{mM}$-MMS for $1 \mathrm{~h}$ at $37^{\circ} \mathrm{C}$ before lysis.

Fig. 7. (a) Determination of the number of apurinic sites plus breaks in MMS-treated $\phi$ X174 RFI, using alkaline $5-20 \%$ sucrose gradients. $(b)$ Determination of the number of breaks introduced into the $\phi \mathrm{X} 174 \mathrm{RFI}$ molecule by non-enzymic hydrolysis at apurinic sites and direct triester breakage, using neutral $5-20 \%$ sucrose gradients. Further details are given in Methods. Control (O); $\phi$ X174 RFI treated with $25 \mathrm{mM}-\mathrm{MMS}$ for $1 \mathrm{~h}$ at $37^{\circ} \mathrm{C}(\boldsymbol{O})$.

chemical depurination followed by enzymic or chemical hydrolysis of apurinic sites, or by a combination of these factors.

An estimate of the number of breaks plus apurinic sites in the nucleoid from MMS-treated cells was obtained by carrying out alkaline sucrose-gradient centrifugations of nucleoid preparations (Fig. 6). A near-symmetrical distribution in the size of DNA fragments was obtained for nucleoids from cells treated with $10 \mathrm{mM}-\mathrm{MMS}$ or with $25 \mathrm{mM}-\mathrm{MMS}$. Based on molecular weight estimation it was calculated that the nucleoids from cells treated with 10 and 25 mM-MMS had, on average, 42 and 100 breaks plus apurinic sites per genome, respectively. In the case of the nucleoid from the polA strain treated with 25 mM-MMS (Fig. 4), similar centrifugation experiments gave a value of approximately 300 breaks plus apurinic sites per genome.

To obtain an estimate of apurinic sites in the DNA caused by non-enzymic depurination, ${ }^{3} \mathrm{H}$-labelled $\phi$ X174 RFI was methylated in vitro, using the same methylating conditions as those used for $E$. coli cells in vivo. Figure 7 shows the results obtained when $\phi$ X174 RFI treated with $25 \mathrm{mM}$-MMS was subjected to alkaline and neutral sucrose-gradient centri- 


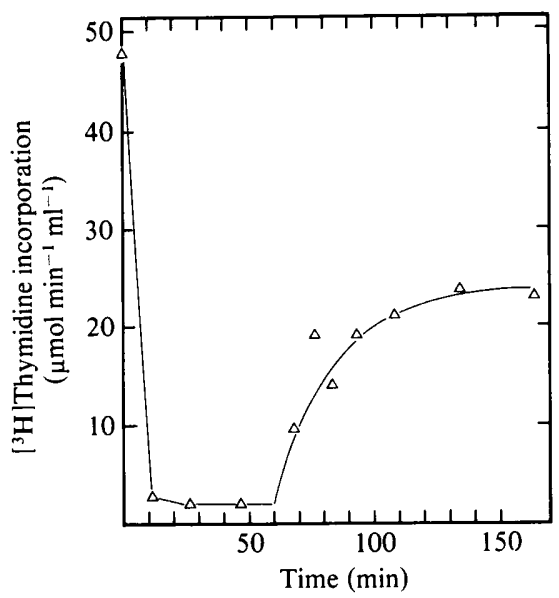

Fig. 8. Incorporation of $\left[{ }^{3} \mathrm{H}\right]$ thymidine during and after treatment of $E$. coli $\mathrm{K} 12$ DG75 with $25 \mathrm{mM}$-MMS at $37^{\circ} \mathrm{C}$. MMS was added to a culture of exponentially growing cells at $t=0$. At $t=$ $60 \mathrm{~min}$, cells were filtered (Millipore RAWP, $0.45 \mu \mathrm{m}$ ) and resuspended in MMS-free minimal medium. Samples of $1 \mathrm{ml}$ were withdrawn at the times indicated and pulse-labelled with $\left[\right.$ methyl $\left.-{ }^{3} \mathrm{H}\right]$ thymidine.

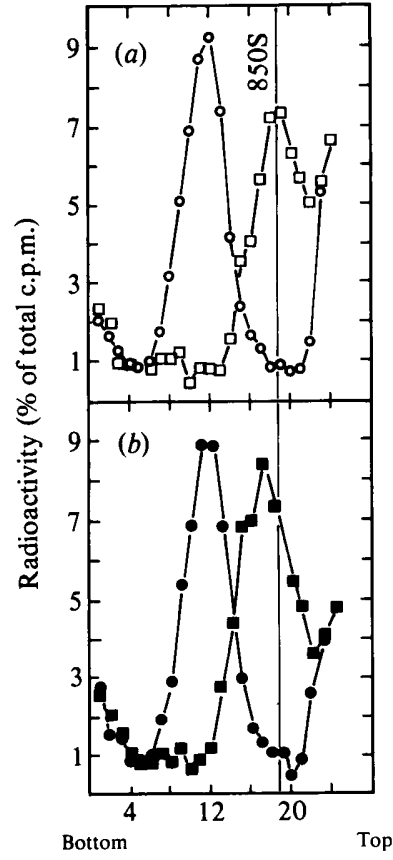

Fraction no.

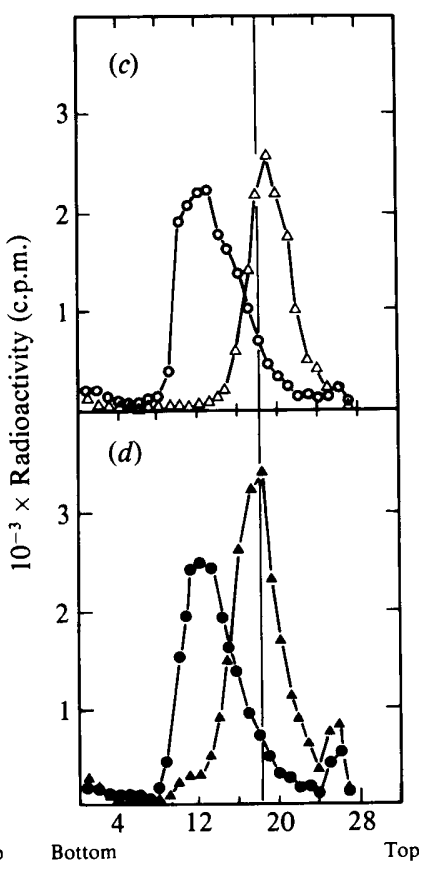

Fraction no.

Fig. 9. Sedimentation pattern of envelope-free nucleoids from $E$. coli K12 DG75 incubated in MMS-free medium for various periods after MMS treatment. The cells were treated with 25 mM-MMS for $1 \mathrm{~h}$ at $37^{\circ} \mathrm{C}$, harvested by centrifugation, resuspended in MMS-free medium and incubated for the times indicated prior to lysis. Nucleoids from untreated cells in the exponential growth phase were used as controls. Further details are given in Methods. $(a, b)$ Neutral $10-30 \%$ sucrose gradients: control $(O) ; 0 \mathrm{~h}$ incubation ( $\square) ; 1 \mathrm{~h}$ incubation $(\square) ; 2 \mathrm{~h}$ incubation $(O) .(c, d)$ Alkaline $5-20 \%$ sucrose gradients: control $(O) ; 0 \mathrm{~h}$ incubation $(\triangle) ; 1 \mathrm{~h}$ incubation $(\Delta) ; 2 \mathrm{~h}$ incubation $(\mathbf{O})$. 


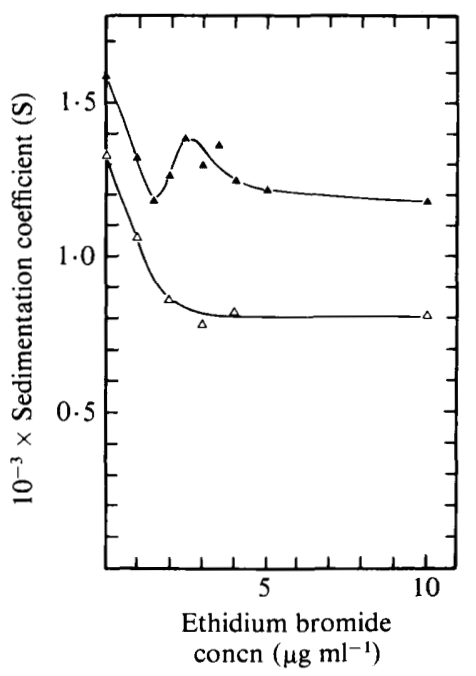

Fig. 10. Sedimentation coefficient as a function of ethidium bromide concentration for envelope-free nucleoids from $E$. coli K12 DG75 incubated in MMS-free medium after MMS treatment. The cells were treated with $25 \mathrm{mM}-\mathrm{MMS}$ for $1 \mathrm{~h}$ at $37^{\circ} \mathrm{C}$, harvested by centrifugation, resuspended in MMS-free medium and incubated for $1 \mathrm{~h}(\Delta)$ or $2 \mathrm{~h}(\Delta)$ prior to lysis. Further details are given in Methods.

fugation. From the conversion of $\phi$ X174 RFI to $\phi$ X174 RFII it was estimated that $2 \cdot 3$ apurinic sites were formed per $\phi$ X174 RFI molecule. It could further be demonstrated that approximately $1.5 \%$ of the breaks in the $\phi$ X174 RFI molecule were introduced by non-enzymic hydrolysis at apurinic sites or by direct triester breakage. This corresponds to a non-enzymic introduction of 1.5 breaks in the $E$. coli genome after treatment with $25 \mathrm{mM}$-MMS for $1 \mathrm{~h}$. Since the rate of methylation in vivo is known to be considerably slower than that in vitro (Thielman et al., 1975), it is highly unlikely that non-enzymic strand breaking in the nucleoid occurs to any extent.

\section{Repair of damage after MMS treatment}

Removal of MMS caused a large increase in the incorporation of thymidine (Fig. 8), suggesting that extensive repair synthesis took place. After $1 \mathrm{~h}$ the rate of incorporation had levelled off and was approximately half that prior to the MMS treatment. The sedimentation properties of the nucleoid after various periods allowed for repair were investigated; the results for $1 \mathrm{~h}$ and $2 \mathrm{~h}$ incubation periods are shown in Fig. 9. After $1 \mathrm{~h}$ incubation in MMS-free medium an increase in sedimentation coefficient of the nucleoid from approximately $850 \mathrm{~S}$ to $1350 \mathrm{~S}$ was observed; after $2 \mathrm{~h}$ the sedimentation coefficient was the same as that of the control. This might suggest that increased folding of the nucleoid occurs during the repair period, i.e. the supercoiling was partially restored. Alkaline sucrose-gradient centrifugation showed that the number of breaks plus apurinic sites was reduced from 100 to the same level as in the control during a repair period of $2 \mathrm{~h}$.

The isolated nucleoids from the cells in which repair had taken place were titrated with ethidium bromide to estimate supercoiling (Fig. 10). For both the $1 \mathrm{~h}$ and $2 \mathrm{~h}$ samples, addition of increasing amounts of ethidium bromide produced a marked decrease in the sedimentation coefficient of the nucleoids. In the case of the $1 \mathrm{~h}$ sample a plateau was observed at $800 \mathrm{~S}$. With the $2 \mathrm{~h}$ sample a minimum was seen at a concentration of ethidium bromide of approximately $1.5 \mu \mathrm{g} \mathrm{ml}^{-1}$, followed by a maximum at $2.5 \mu \mathrm{g} \mathrm{ml}^{-1}$ and a plateau region of approximately $1300 \mathrm{~S}$. Since the sedimentation coefficient of the nucleoid and the number of breaks plus apurinic sites were the same for the $2 \mathrm{~h}$ sample as for the control, one 
would expect the ethidium bromide titration curve of this sample to be similar to that of the control. The reasons for the differences are not fully understood at present.

\section{DISCUSSION}

The present results clearly demonstrate that the methylating agent MMS causes profound changes in the nucleoid structure of $E$. coli K 12 DG75 at concentrations which rapidly inhibit the growth of the cells.

It is known that MMS reacts fairly rapidly with biological macromolecules (Singer, 1975). With $25 \mathrm{mM}-\mathrm{MMS}$, changes in the nucleoid structure were first seen after $1 \mathrm{~h}$. The same concentration of MMS caused almost immediate inhibition of growth. The decrease in sedimentation coefficient observed is probably caused by relaxation of supercoils in the nucleoid. Relaxation of supercoils has also been demonstrated in vitro after treatment with DNAase (Worcel \& Burgi, 1972; Pettijohn \& Hecht, 1973). In the present case 25 mM-MMS gave an average of 100 breaks plus apurinic sites per genome after $1 \mathrm{~h}$ incubation in vivo. Models for the isolated nucleoid suggest that it consists of a number of independent loops which can be relaxed separately (see Kleppe et al., 1979). Estimates of the number of loops have varied; the most recent study suggests a number of $100 \pm 30$ (Lydersen \& Pettijohn, 1977). The average number of breaks plus apurinic sites created by $25 \mathrm{mM}-\mathrm{MMS}$ in $1 \mathrm{~h}$ is therefore about the same as the number of loops in the nucleoid. Furthermore, it is also approximately the same as that found in DNAase-treated nucleoids of similar sedimentation coefficient (Worcel \& Burgi, 1972). Therefore, it is likely that the breaks plus apurinic sites determined in this work in fact consist mostly of breaks. Relaxation of supercoils in the nucleoid leads to a loss of the tertiary structure and this would be in agreement with the light and electron microscope observations of MMS-treated cells.

The fact that no change in the sedimentation coefficient of the nucleoid was observed after short periods of MMS treatment, despite the fact that increasing numbers of breaks could be demonstrated, might suggest that the supercoils are partially restrained in vivo. An effect on the sedimentation coefficient would therefore first be observed only after a considerable number of breaks had been introduced. A similar conclusion has been reached by Pettijohn \& Pfenninger (1979) using $\gamma$ rays to produce nicks in DNA in vivo.

A change in the amount of RNA in the nucleoid might, however, also explain the decrease in the sedimentation rate, since RNA is known to stabilize the isolated nucleoid (Pettijohn \& Hecht, 1973; Hecht \& Pettijohn, 1976). DNA and RNA analyses showed, however, that the DNA : RNA ratio remained unchanged during the MMS treatment.

The question must now be considered as to the mechanism of induction of breaks in the DNA strands of the nucleoid. An extensive review of repair mechanisms, dealing also with MMS, has recently been published (Roberts, 1978). In addition to methylation of bases, MMS can cause both depurination and strand breakage (Laurence, 1963; Lawley, 1966; Lindahl \& Andersen 1972; Singer, 1975). It appears that in bacteria the methylated bases are not excised to any extent when MMS is used as a methylating agent (Prakash \& Strauss, $1970)$. With other methylating agents such as $N$-methyl- $N^{\prime}$-nitro- $N$-nitrosoguanidine, excision of certain methylated products can be demonstrated (Lawley \& Orr, 1970). Studies with $\phi$ X174 RFI DNA in this work showed that apurinic sites were produced by incubation of the DNA with MMS. Apurinic sites could also have been created by the enzyme 3-methyl adenine glycosylase (Lindahl, 1976) and other glycosylases. The apurinic sites thus created could then serve as substrates for the apurinic specific endonucleases (AP endonucleases) of E. coli (Verly \& Paquette, 1972; Radman, 1976; Ljungquist, 1977; Gates \& Linn, 1977; Gossard \& Verly, 1978), resulting in strand breakage. The fact that MMS treatment in vitro of the isolated nucleoid caused no significant change in the sedimentation coefficient suggests that non-enzymic hydrolysis of apurinic sites is of little importance. Control experiments with $\phi \mathrm{X} 174$ also confirmed this view. 
In the two MMS-sensitive strains studied, the chromosome contained considerably more strand breaks after MMS treatment than that in the insensitive strain. This would then result in increased viscosity of the DNA and complete collapse of the tertiary structure of the nucleoid. DNA from such MMS-treated cells is known to be of relatively small molecular weight when examined in alkaline sucrose gradients (Boris et al., 1971). This was also confirmed in the present work. Cell lethality might therefore, as previously suggested (Scudiro et al., 1973), be a consequence of increased amounts of non-repaired breaks in the DNA. The destruction of the nucleoid structure which occurs as a result of the increased number of gaps in the DNA may also have far-reaching implications with regard to the control of important processes such as transcription, separation of chromosomes and DNA replication. Thus, for repair to be complete it must be assumed that the supercoiling, which is lost, must be introduced again into the chromosome so that the original nucleoid structure is restored.

Treatment of bacteria with MMS obviously affects other control mechanisms in the cell in addition to those connected with the chromosome. The methylation of, for example, membrane proteins and ribosomes is probably also of great importance with regard to growth inhibition (Singer, 1975). The electron microscope results in this work revealed that MMS also caused alterations in the cell envelope. Further studies are needed to establish in more detail the influence of MMS on the various metabolic processes.

The mechanism of action of other methylating agents on the nucleoid structure might be different from that of MMS. Results from our laboratory (unpublished) have shown that mitomycin $\mathrm{C}$ at low concentrations causes rapid and profound changes in the tertiary structure of the nucleoid from E. coli.

This study was supported in part by a grant from the Norwegian Research Council for Science and Humanities. We are grateful to Drs C. Korch and S. Øvrebø for many helpful discussions.

\section{REFERENCES}

Boris, I., Sinziuis, G. B., Smirnov, G. B. \& Saenko, A. S. (1971). Effect of polA1 mutation on the ability of Escherichia coli K-12 to repair single-strand breaks of DNA induced by methyl methanesulfonate. Biochimica et biophysica acta 247, 635639.

BRENT, T. (1975). Partial purification of an endonuclease activity from human lymphoblasts. Separation of activities for depurinated DNA and DNA irradiated with ultraviolet light. Biochimica et biophysica acta 407, 191-199.

Bridges, B. A., Mottershead, R. P., Green, M. L. \& GRAY, W. J. H. (1973). Mutagenicity of dichlorvos and methyl methanesulphonate for Escherichia coli WP2 and some derivatives deficient in DNA repair. Mutation Research 19, 295-303.

Clark, J. D. \& MAaløE, O. (1967). DNA replication and division cycle in Escherichia coli. Journal of Molecular Biology 23, 99-112.

DrlicA, K. \& SNYDER, M. (1978). Superhelical Escherichia coli DNA: relaxation by coumermycin. Journal of Molecular Biology 120, 145-154.

DrliCA, K. \& WorCEL, A. (1975). Conformational transitions in the Escherichia coli chromosome: analysis by viscometry and sedimentation. Journal of Molecular Biology 98, 393-411.

DWORSKY, P. \& SCHAEChTER, M. (1973). Effect of rifampin on the structure and membrane attachment of the nucleoid of Escherichia coli. Journal of Bacteriology 116, 1364-1374.

EISENSTARK, A. (1967). Bacteriophage technique. Methods in Virology 1, 449-525.
Gates, F. T. \& LinN, S. (1977). Endonuclease V of Escherichia coli. Journal of Biological Chemistry 252, 1647-1653.

Gossard, F. \& Verly, W. G. (1978). Properties of the main endonuclease specific for apurinic sites of Escherichia coli (endonuclease VI). European Journal of Biochemistry 82, 321-332.

Gross, J. \& Gross, M. (1969). Genetic analysis of an Escherichia coli strain with a mutation affecting DNA polymerase. Nature, London 224, 1166-1168.

Hecht, R. \& Pettuohn, D. E. (1976). Studies on DNA-bound RNA molecules isolated from nucleoids of Escherichia coli. Nucleic Acids Research 3, 767-788.

Hecht, R., Stimpson, D. \& Pettijohn, D. E. (1977). Sedimentation properties of the bacterial chromosome as an isolated nucleoid and as an infolded DNA fiber. Chromosomal DNA folding measured by rotor speed effects. Journal of Molecular Biology $111,257-277$.

HowARD-Flanders, P. \& BOYCE, R. P. (1966). DNA repair and genetic recombinations: studies on mutants of Escherichia coli defective in these processes. Radiation Research, Supplement 6, 156184.

KAvenoff, R. \& Bowen, B. C. (1976). Electron microscopy of membrane-free folded chromosomes from Escherichia coli. Chromosoma 59, 89-101.

KENNEL, D. (1967). Use of filters to separate radioactivity in RNA, DNA and protein. Methods in Enzymology 12A, 686-695. 
KLEPPE, K. \& Lossius, I. (1978). Influence of mutagens on the nucleoid structure of the chromosome in Escherichia coli. 78 th Annual Meeting of American Society for Microbiology, Las Vegas, p. 125.

KLEPPE, K., Øvrebø, S. \& Lossius, I. (1979). The bacterial nucleoid. Journal of General Microbiology 112, 1-13.

KorCH, C., Øvrebø, S. \& Kleppe, K. (1976). Envelope-associated folded chromosomes from Escherichia coli: variations under different physiological conditions. Journal of Bacteriology 127, 904-916.

KRÜGER, P. G. \& BloOM, G. (1974). Structural features of histamine release in rat peritoneal mast cells. International Archives of Allergy and Applied Immunology 46, 740-752.

LAURENCE, D. (1963). Chain breakage of deoxyribonucleic acids following treatment with low doses of sulphur mustards. Proceedings of the Royal Society B271, 520-530.

LAWLEY, P. D. (1966). Effects of some chemical mutagens and carcinogens on nucleic acids. Progress in Nucleic Acid Research and Molecular Biology 5, 89-131.

LAWLEY, P. D. (1974). Some chemical aspects of dose-response relationships in alkylation mutagenesis. Mutation Research 23, 283-295.

LAWLEY, P. D. \& ORR, D. J. (1970). Specific excision of methylation products from DNA of Escherichia coli treated with $N$-methyl- $N^{\prime}$-nitro- $N$-nitrosoguanidine. Chemico-Biological Interactions 2, 154-158.

LINDAHL, T. (1976). A new class of enzymes acting on damaged DNA. Nature, London 259, 64-66.

LINDAHL, T. \& ANDERSON, A. (1972). Rate of chain breakage at apurinic sites in double-stranded deoxyribonucleic acid. Biochemistry 11, 3618-3623.

LJUNQuisT, S. (1977). A new endonuclease from $E$. coli acting at apurinic sites in DNA. Journal of Biological Chemistry 252, 2808-2814.

LJUNGQUiST, S., LINDAHL, T. \& HowARD-FlandERS, P. (1976). Methyl methane-sulphonate mutants of Escherichia coli deficient in an endonuclease specific for apurinic sites in deoxyribonucleic acid. Journal of Bacteriology 126, 646-653.

Lydersen, B. K. \& PetTún, D. E. (1977). Interactions stabilizing DNA tertiary structure in the Escherichia coli chromosome investigated with ionizing radiation. Chromosoma 62, 199-215.

NES, I. F. \& NisSEN-MEYER, J. (1978). Endonuclease activities from a permanently established mouse cell line that act upon DNA damaged by ultraviolet light, acid and osmium tetraoxide. Biochimica et biophysica acta 520, 111-121.

Øvrebø, S. \& KorCH, C. (1978). Bacterial nucleoid structure after inhibition of DNA replication: the role of RNA synthesis. In DNA Synthesis: Present and Future, pp. 439-445. Edited by I. Molineux \& M. Kohiyama. New York \& London: Plenum Press.

Petrijohn, D. E. (1976). Procaryotic DNA in nuc leoid structure. CRC Critical Reviews in Biochemistry 4, 175-202.

Pettijohn, D. E. \& Hecht, R. (1973). RNA molecules bound to the folded bacterial genome stabilize DNA folds and segregate domains of supercoiling. Cold Spring Harbor Symposia on Quantitative Biology 38, 31-42.
Pettijohn, D. E. \& Pfenninger, O. (1979). DNA supercoils restrained in vivo in prokaryotic cells. XIth International Congress of Biochemistry, Toronto, p. 31, abstract O1-3-H6.

Pettijohn, D. E., Hecht, R. M., Stonington, O. G. \& Stamato, T. D. (1973). Factors stabilizing DNA folding in bacterial chromosomes. In DNA Synthesis in vitro, pp. 145-163. Edited by R. D. Wells \& R. B. Inman. Lancaster: Medical and Technical Publishing Co.

Prakash, L. \& Strauss, B. (1970). Repair of methylation damage: stability of methyl groups in Bacillus subtilis treated with methyl methane sulphonate. Journal of Bacteriology 102, 760-766.

RADMAN, M. (1976). An endonuclease from Escherichia coli that introduces single polynucleotide chain scissions in ultraviolet irradiated DNA. Journal of Biological Chemistry 251, 14381445.

Rhaese, H. J. \& Freese, E. (1969). Chemical analysis of DNA alterations. IV. Reactions of oligodeoxynucleotides with monofunctional alkylating agents leading to backbone breakage. Biochimica et biophysica acta 190, 418-433.

RoBERTS, J. J. (1978). The repair of DNA modified by cytotoxic, mutagenic and carcinogenic chemicals. Advances in Radiation Biology 7, 211-436.

Scudiro, D., Friesen, B. \& Baptist, B. A. (1973). Physiological modifications in the production and repair of methyl methane sulfonate-induced breaks in the deoxyribonucleic acid of Escherichia coli K-12. Journal of Bacteriology 114, 267-272.

SINGER, B. (1975). The chemical effects of nucleic acid alkylation and their relation to mutagenesis and carcinogenesis. Progress in Nucleic Acid Research 15, 219-280.

SINGER, B. (1977). Nucleic acid alkylation, mutation and carcinogenesis: is there a relationship? Trends in Biochemical Sciences 2, 180-183.

Stonington, O. G. \& Petrijohn, D. E. (1971). The folded genome of Escherichia coli isolated in a protein-DNA-RNA complex. Proceedings of the National Academy of Sciences of the United States of America 68, 6-9.

STUDIER, F. W. (1965). Sedimentation studies of the size and shape of DNA. Journal of Molecular Biology 11, 373-390.

ThielmanN, H. W., Vosberg, H. P. \& Reygers, V. (1975). Carcinogen-induced DNA repair in nucleotide-permeable Escherichia coli cells. Induction of DNA repair by the carcinogens methyl and ethyl nitrosourea and methyl methanesulfonate. European Journal of Biochemistry 56, 433-447.

Verly, W. G. \& Paquette, Y. (1972). An endonuclease for depurinated DNA in Escherichia coli B. Canadian Journal of Biochemistry 50, 217-224.

WORCEL, A. \& BURGI, E. (1972). On the structure of the folded chromosome of Escherichia coli. Journal of Molecular Biology 71, 127-147.

Worcel, A. \& Burgi, E. (1974). Properties of a membrane-attached form of the folded chromosome of Escherichia coli. Journal of Molecular Biology 82, 91-105.

Yамамото, Y., Katsuki, M., Sekiguchi, M. \& Otsuj,, N. (1978). Escherichia coli gene that controls the sensitivity to alkylating agents. Journal of Bacteriology 135, 144-152. 